\title{
DISEMINASI MANUSKRIP ISLAM PADA PERPUSTAKAAN ONLINE
}

\section{Muhammad Taqiyuddin, Muhammad Faqih Nidzom, Ahmad Rijal Khoirudin}

\begin{abstract}
Abstrak
Manuskrip Kuno perlu proses digitalisasi. Selain sebagai dokumen masa lalu, benda tersebut berisi informasi dan referensi yang penting bagi pemetaan pengetahuan yang belum dapat kita akses. Belum lagi, secara metodis dan ideologis, kajian manuskrip akan turut mengungkap etos ilmiah penulisnya yang patut ditiru dalam konteks modern dan globalisasi ini. Sehingga, diseminasi manuskrip menjadi penting. Khususnya, demi memahami bahwa peradaban Islam adalah peradaban Ilmu. Kajian pustaka ini berusaha mengungkap fenomena digitalisasi manuskrip Islam kuno di perpustakaan online internasional. Manuskrip Islam yang dimaksud dibatasi pada disiplin ilmu alam tertentu. Sehingga, dapat ditelaah secara linear dan dibandingkan dari berbagai seginya. Penelitian ini menemukan bahwa perpustakaan online di skala internasional, tergolong sangat memperhatikan peninggalan intelektual berupa manuskrip Islam. Hal ini dibuktikan dengan cukup banyaknya koleksi mereka yang berupa manuskrip Islam klasik, yang sebagian telah diedit dan dialihbahasakan. Digitalisasi ini akan menarik ahli-ahli untuk mengkaji manuskrip tersebut secara kritis, sehingga menjadi kontribusi ilmiah yang signifikan dalam bidang sejarah sains.
\end{abstract}

Kata Kunci: Perpustakaan Online, Manuskrip Kuno, Digitalisasi Manuskrip, Peradaban Islam

\begin{abstract}
Ancient Manuscripts need to be digitized. Apart from being past documents, these objects contain important information and references for mapping knowledge that we have not yet had access to. Not to mention, methodically and ideologically, the study of the manuscripts will also reveal the author's scientific ethos which should be emulated in this modern and globalization context. Thus, manuscript dissemination is important. In particular, for the sake of understanding that Islamic civilization is a science civilization. This literature review attempts to uncover the phenomenon of digitizing ancient Islamic manuscripts in international online libraries. The Islamic manuscripts in question are limited to certain natural disciplines. So, it can be analyzed linearly and compared from various aspects. This study found that online libraries on an international scale are classified as very concerned about intellectual heritage in the form of Islamic manuscripts. This is
\end{abstract}


evidenced by their quite large collection of classical Islamic manuscripts, some of which have been edited and translated. This digitization will attract experts to critically examine the manuscript, so that it will become a significant scientific contribution in the field of the history of science.

Keywords: Online Library, Ancient Manuscript, Digitalization, Islamic Civilization 


\section{PENDAHULUAN}

Perpustakaan online sudah menjadi tren baru di era digital ini. Bahkan, banyak literatur gratis yang bisa diakses melalui platform tersebut. Di satu sisi, banyak penelitian yang membutuhkan literatur gratis sejenis ini. Namun, informasi terkait perpustakaan online ini, khususnya di luar negeri, masih belum banyak diakses masyarakat akademik. Entah terkait kekurangan dalam kompetensi bahasa Inggris atau Arab, entah juga karena rumitnya antarmuka (interface) dari struktur perpustakaan online tersebut.

Di antara literatur yang cukup menjadi tren saat ini, adalah tema sejarah sains. Di luar negeri, kajian sejarah sains menempati posisi yang cukup populer; karena dengannya, pembicaraan tentang pengembangan sains dan teknologi menjadi lebih detail. Namun problemnya, salah satu tema dari kajian ini adalah editing manuskrip. Meski rumit, ini adalah tema yang sangat penting. Karena, suatu manuskrip mengandung berbagai informasi yang didokumenkan di saat manuskrip itu dibuat. Sehingga, filolog atau ahli sejarah dapat mengusahakan sebuah rekonstruksi sederhana tentang suasana sosial pada masa tersebut.

Dalam hal ini, ketersediaan manuskrip sejatinya sudah seperti menjadi kewajiban negara atau institusi akademik; dalam hal ini perpustakaan. Di Indonesia saja, hampir setiap daerah memiliki perpustakaan dengan koleksi lawas, hingga manuskrip kuno yang masih dalam proses editing. Di antara perpustakaan yang cukup berperan besar adalah Perpustakaan Nasional (Perpusnas), setidaknya telah mengumpulkan koleksi spesial bidang naskah islam di nusantara. Sebagian darinya juga telah diedit dan diterbitkan menjadi buku dalam katalog hingga versi online. Usaha ini, tentu sangat perlu diapresesiasi oleh kita semua, mengingat urgensi naskah kuno sebagai sarana mengkaji sejarah masa lalu. Sehingga, jika proses diseminasi pengetahuan ini berjalan lancar, wawasan masyarakat muslim Indonesia dapat lebih terluaskan.

Proses digitalisasi memang sangat berperan dalam diseminasi manuskrip kuno. Fakta ini dibuktikan oleh berbagai penelitian. Di antaranya, kajian bertema digitalisasi sebagai sarana pelestarian. Di 
antaranya dilakukan oleh 1) Tuti Hendrawati; 2) Diki Tri Wibowo dan Lydia Christiani; juga 3) Intan Prastiani dan Slamet Subekti, serta 4) Husan dan Muhammad Tajuddin. Keempat penelitian tersebut memiliki kesamaan tujuan, di antaranya menekankan pentingnya digitalisasi sebagai sarana pelestarian dan diseminasi pengetahuan dari manuskrip kuno. Tujuannya, agar pihak atau orang yang berkompetensi dalam filologi turut mendapat kesempatan dalam berusaha mengungkap isi manuskrip tersebut. Tujuan lainnya, yakni melestarikan konten berupa kearifan lokal yang terdapat dalam manuskrip tersebut (Anwar, Husain, and Jaya 2018; Hendrawati 2019; Prastiani and Subekti 2019; Wibowo and Christiani 2018). Perbedaannya terletak pada obyek penelitian masing-masing; yakni studi kasusnya.

Sedangkan kajian yang paling mendekati tema penelitian saat ini, yakni tentang diseminasi manuskrip di perpustakaan online internasional, telah ditulis oleh beberapa orang. Di antaranya 1) Rozikin Mochammad dkk; 2) Hendra Junawan; 3) Stratton L. Ladewig dan Robert D. Marcello; serta 4) Cornelis van Lit. Seluruh penelitian di atas fokus pada teknis diseminasi konten dalam perpustakaan online. Dua penelitian di awal, lebih detail pada konsep perpustakaan digital secara umum (Junawan 2020; Mochammad, Ardika, and Cahyono 2020); Sedangkan nomor 3 dan 4 secara khusus membahas manuskrip kuno. Nomor 3 mengkhususkan pembahasan tentang manuskrip terkait Perjanjian Baru (Bible)(Ladewig and Marcello 2019); sedangkan nomor 4 lebih fokus pada kajian manuskrip oriental berbahasa Arab(van Lit 2019).

Berdasarkan penelitian sebelumnya, belum ditemukan kajian yang khusus mengkaji diseminasi manuskrip sains Islam di perpustakaan online internasional. Sehingga, penelitian ini - setidaknya memiliki kebaruan (novelty) yang khusus. Yakni melacak beberapa perpustakaan online serta beberapa sampel di dalamnya yang terkait dengan sains Islam sebagaimana akan dibatasi dalam metode penelitian. Harapannya, penelitian ini dapat memperkaya wawasan seputar manuskrip Islam yang masih banyak terdapat di perpustakaan internasional; yang sebagian besar darinya belum 
diedit atau ditranskrip. Sehingga, memunculkan dorongan bagi pengkaji pemula atau professional untuk meninjaunya; hingga menelitinya. Karena, beberapa di antaranya telah terkenal dalam sejarah peradaban Islam.

\section{METODE}

Penelitian ini berjenis kajian pustaka (library research). Yang mengandalkan survey literature seputar perpustakaan online internasional yang turut menyediakan versi digital dari sebuah manuskrip kuno. Sedangkan manuskrip kuno yang dimaksud dalam penelitian ini, dibatas pada manuskrip Islam yang memiliki corak Sains Islam. Khususnya dari segi ilmu terapan non sosial. Studi ini fokus pada kasus beberapa perpustakaan online internasional; yakni terbatas pada World Digital Library (https://www.wdl.org/en/), Qatar Digital Library (https://www.qdl.qa/en), The British Library, (https://www.bl.uk/), dan Filaha (http://www.filaha.org/).

Data tentang manuskrip Islam yang disediakan secara online, diperoleh melalui pencarian (searching/browsing) pada website tersebut dengan kata kunci semisal 'islamic science' atau 'arabic science'. Manuskrip yang dicari dibatasi pada kata kunci yang berkaitan dengan subyek keilmuan tertentu. Dalam hal ini dibatasi pada: agriculture, arithmetic, dan astronomy. Data yang didapatkan dianalisa secara deskriptif. Yakni identitas website, teknis perolehan manuskrip, contoh manuskrip yang sesuai obyek penelitian.

\section{HASIL DAN PEMBAHASAN}

Manuskrip sains Islam sejatinya memiliki nilai khusus. Baik secara historis maupun ideologis. Jika manuskrip tersebut menjelaskan suatu penemuan sains, tentunya ia menjadi bagian dari sirklus filosofis yan melibatkan program riset. Hal ini, tentu bersinggungan dengan filsafat ilmu secara umum. Yakni bahwa saintis sebagai penemu bukanlah orang yang tidak memiliki visi dan tujuan dalam pengembangan sains. Bahkan motif agama dapat dikategorikan sebagai sumber inspirasi atau pendorong penelitian.(Muslih 2016) 
Sehingga, mengkaji manuskrip kuno tentang sains Islam bukan sekedar pekerjaan arkeologis atau pelestarian budaya dan warisan intelektual. Lebih dari itu, ia bisa merupakan usaha menghidupkan kembali spirit dan tradisi keilmuan Islam. Yang mana, kemajuan peradaban Islam sejatinya adalah kemajuan bidang pengetahuan. Terbukti, bahwa pada masa tersebut, para ilmuwan muslim mengumpulkan berbagai literatur dari peradaban sebelumnya untuk dipelajari. Sehingga, pengembangan keilmuan menjadi pesat dan mendukung peradaban tersebut menjadi maju.(Sahidi 2020)

Fakta ini, nampaknya perlu diusahakan untuk digali kembali. Yakni, warisan intelektual dari peradaban Islam di masa kuno. Hal ini, justru malah menjadi kesadaran di dunia Barat; yakni dengan maraknya berbagai kajian tentang sejarah sains. Di antara topiknya adalah menggali koleksi manuskrip kuno dan mempelajarinya. Sebagian besar bahkan sudah diedit menjadi karya yang terbit berbentuk buku atau jurnal ilmiah. Manuskrip tersebut, justru diperoleh dari universitas di negara barat. Yang saat ini, mulai banyak membuka akses digital atas koleksi tersebut. (van Lit 2019)

\section{Perpustakaan Digital (Online)}

Digitalisasi konten, sudah seolah menjadi tuntutan di era global ini. Sehingga, membuat traffic kunjungan ke website perpustakaan menjadi meningkat; apalagi setelah pengunjungnya menemukan konten yang bermanfaat baginya. Secara gratis dan tidak banyak kesulitan. Ketertarikan pengunjung website pun beragam, ada yang sekedar melihat desain web, ada pula yang memanfaatkan layanan pinjam buku atau pencarian literatur yang dibutuhkan untuk kajian akademik. Bahkan, ada pula yang mencari koleksi langka dari perpustakaan tersebut.(Nugroho and Isnainy 2020; Pertiwi and others 2020)

Kemudahan akses menjadi pilihan yang utama dalam melakukan browsing. Apalagi, jika konten yang disediakan memiliki mutu yang tinggi; serta mengandung kebaruan ilmiah yang dapat berpeluang mendorong kemajuan dan pengembangan ilmu. Dalam skala internasional, 
infrastruktur tersebut memang sudah lazim. Apalagi di negara yang maju, dengan kapasitas layanan internet terintegrasi dengan kuat di universitas. Sehingga, faktor inilah yang salah satunya mempermudah sivitas akademika dalam mengakses hal-hal yang ingin ditelitinya. Jika fasilitas tersebut tercapai, suatu karya ilmiah dimungkinkan lebih cepat selesai. Terbitnya sebuah karya ilmiah yang berbobot dapat mempercepat perkembangan ilmu.(Ye et al. 2020)

Dalam hal penelitian ini, difokuskan pada beberapa perpustakaan online internasional yang menyediakan layanan akses kepada manuskrip Islam kuno. Yakni terbatas pada literatur tentang sains Islam. Website atau perpustakaan online yang dikaji hanya terbatas empat saja. Dikarenakan, perpustakaan tersebut memiliki koleksi yang seolah saling melengkapi satu sama lain. Tentu saja, meski akan banyak terdapat portal lainnya. setidaknya, website yang dikaji ini tergolong cukup aktif dan memiliki koleksi yang banyak dan sebagian diantaranya cukup langka.

Koleksi langka memang selalu menarik perhatian. Apalagi, yang berbentuk manuskrip dengan tata huruf dan tulisan yang cukup rumit. Tentu menjadikan tantangan tersendiri bagi filolog dan penggemar nashkah kuno. Jika berhasil melakukan editing atasnya, tentu menjadi suatu prestasi akademik tersendiri; belum lagi jika menemukan fakta yang baru atau perspektif yang hangat dalam pemecahan suatu permasalahan akademik. (Cushman 2020) Dalam dunia internasional, tentulah beberapa perpustakaan ini cukup dikenal dalam menyediakan akses untuk manuskrip. Di antaranya adalah:

Tabel 1. Perpustakaan Online yang diteliti

\begin{tabular}{lllll}
\hline No & Nama & Url & Peluncuran & Pengelola \\
\hline 1 & World & https://www.wdl.org/en/ & 21 April & UNESCO dan \\
& Digital & & 2009 & Library of \\
& Library & & & Congress \\
2 & Qatar & https://www.qdl.qa/en & Oktober & Qatar \\
& Digital & & 2014 & Foundation \\
& Library & & & \\
\hline
\end{tabular}




\begin{tabular}{lllcl}
\hline 3 & The British & https://www.bl.uk/ & November & Negara \\
& Library & & 2011 & Inggris \\
4 & Filāha & http://www.filaha.org/ & 14 April & Dr Karim \\
& Texts & & 2011 & Lahham (FTP \\
& Project & & & community) \\
\hline
\end{tabular}

Daftar di atas merupakan beberapa perpustakaan online di dunia. Yang secara khusus menyediakan akses bagi pengunjung untuk mencari manuskrip yang diinginkan. Tentu dari segi kelengkapan, akan terdapat perbedaan. Satu hal yang menjadi ciri khususnya; bahwa hampir seluruhnya saling bertukar koleksi. Perpustakaan di nomor 1, 2, dan 3 cenderung saling berbagi konten secara online. Misalnya, suatu manuskrip di World Digital Library dapat diakses di Qatar Digital Library atau The British Library. Meskipun, manuskrip tersebut disimpan di The British Library atau lainnya.

Identifikasi lebih lanjut pada metode pengumpulan koleksinya, menemukan bahwa manuskrip tersebut didapat dari berbagai cara. Baik membeli naskah(Woldeyes 2020), eksplorasi ke rumah penduduk asli yang menyimpannya(Lliteras 2020), maupun hibah dari personal atau tokoh orientalis. Karena, hampir orientalis yang turut serta dalam invasi ke negara Afrika dan Arab, ikut 'andil menyelamatkan' manuskrip dari aktivitas militeristik (Ghobrial 2016; Riedel 2015; Woldeyes 2020).

\section{World Digital Library}

Merupakan perpustakaan digital yang diluncurkan oleh UNESCO dan 32 lembaga mitranya pada 21 April 2009, perpustakaan ini berbentuk situs web yang menampilkan materi berbasis budaya unik dari perpustakaan dan arsip dari seluruh dunia. Situs yang beralamat www.wdl.org mencakup manuskrip, peta, buku langka, film, rekaman suara, cetakan dan foto. Ini memberikan akses publik yang tidak terbatas dan gratis ke materi koleksi tersebut (Abid 2009).

Fokus pada koleksi tentang manuskrip sains Islam, setidaknya ditemukan beberapa tema di dalamnya. Baik dari segi bahasa, 
astronomi, matematika, veteriner, dan lainnya (Nasreen, Bashir, and Loan 2019; Van Oudenaren 2017).

Dalam menemukan manuskrip dengan tema sains Islam, digunakan kata kunci (keyword) untuk penelusuran di web tersebut. Kata kunci yang digunakan adalah Islamic Science. Dari penelusuran, ditemukan 559 hasil.

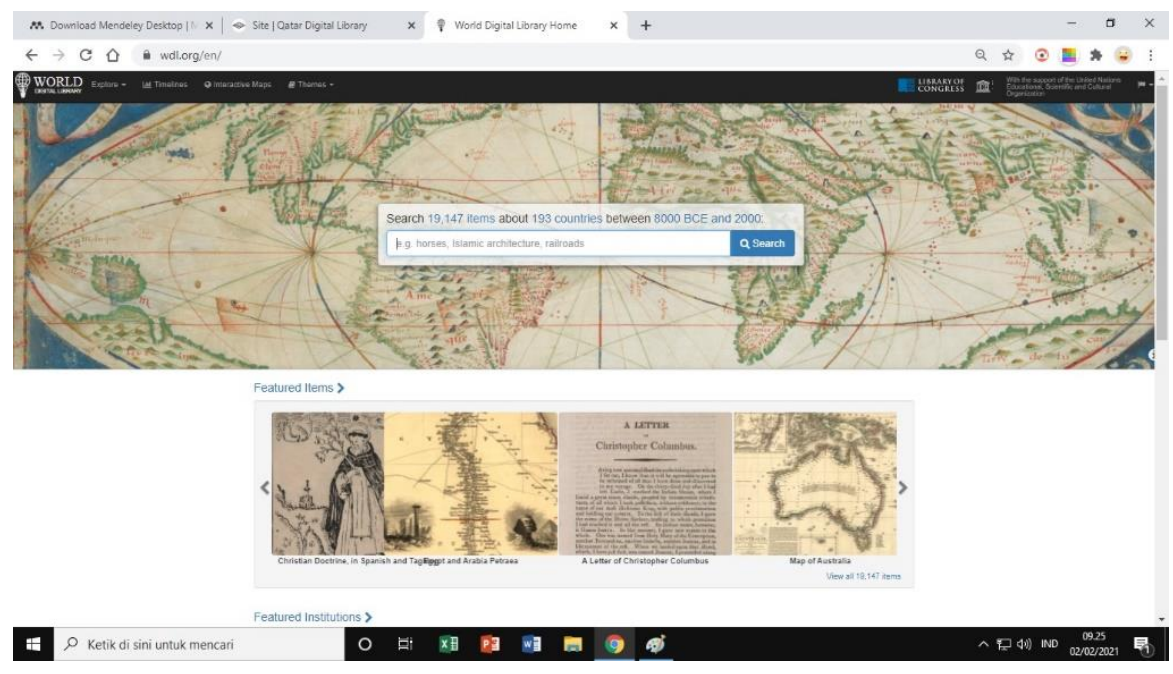

Gambar 1. Halaman utama World Digital Library

Dalam penelusuran file manuskrip, tidak jarang bahwa klasifikasinya sulit dilakukan. Sehingga, dalam hasil penelusurannya terkadang ikut masuk di dalamnya manuskrip al-Qur'an. Namun, beberapa hasil yang dipilih untuk ditampilkan di indeks berikut hanyalah yang terkait dengan sains seperti Logika, Astronomi, Aritmatika, maupun militer. Berikut ini ringkasan indeks tentang koleksi manuskrip bertema sains Islam yang didapat dari perspustakaan digital tersebut:

Tabel 2. Karya dan Penulis Manuskrip di World Digital Library

\begin{tabular}{|c|c|c|c|}
\hline Nama Penulis & Tahun & Domisili & Periode \\
\hline $\begin{array}{c}\text { Umar Ibn Sahlan } \\
\text { al-Sawi }\end{array}$ & $?-1109 \mathrm{M}$ & Iran & Seljuk \\
\hline ibn al-Ha'im & $1356-1412 \mathrm{M}$ & Mesir/Afrika & Utsmani \\
\hline $\begin{array}{c}\text { Anonim } \\
\text { (Aritmatika) }\end{array}$ & $1500-1699 \mathrm{M}$ & Timbuktu & Mali \\
\hline $\begin{array}{c}\text { Abi Talib al-Sufi } \\
\text { al-Ansari }\end{array}$ & $1257-1327 \mathrm{M}$ & Damaskus & Abbasiyah \\
\hline
\end{tabular}


'Ali al-

Marrakushi

$$
\begin{gathered}
?-1262 \mathrm{M} \\
?-1342 \mathrm{M} \\
1203-1283 \mathrm{M} \\
?-1221 \mathrm{M}
\end{gathered}
$$

Maroko - Mesir

Mamluk

Aidamur al-

Jaldaki

Afganistan

Mamluk

al-Qazwīnī

Iran

Abbasiyah

'Umar al-

Khiva

Jig̈hmīn̄i

(Uzbekistan)

Berikut ini adalah salah satu koleksi manuskrip yang terdapat dalam website tersebut. Yakni, karya Aidamur ibn 'Ali ibn Aidamur alJaldaki (? - 1342 M) yang berjudul Anwār al-bayān wa asrār alburhān fĩ fahm awzān 'ilm al-mīzān. Ditulis berbahasa Arab, dan telah disalin ulang dari manuskrip aslinya.

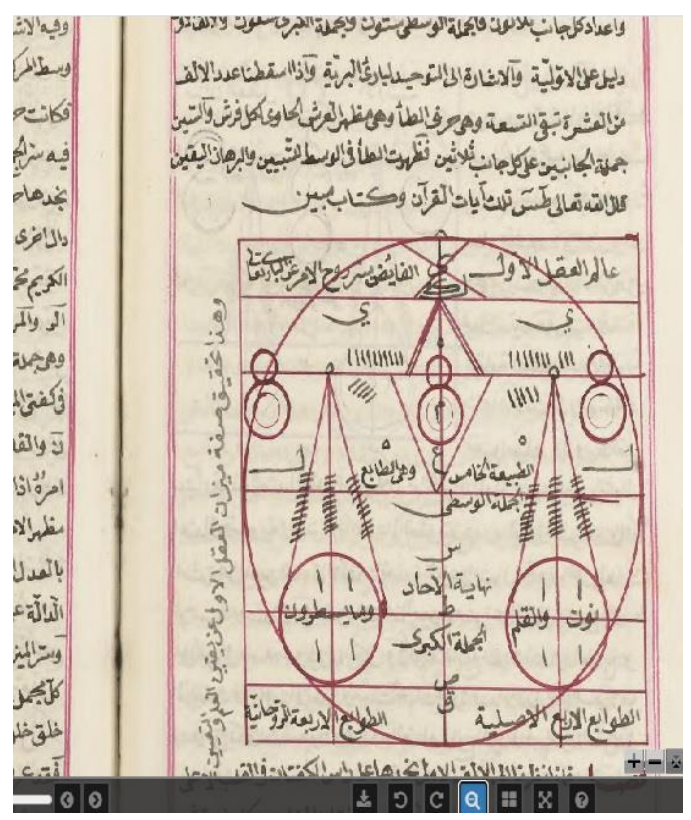

Gambar 2. Salah satu manuskrip yang kondisinya baik dan dapat diakses.

Terlihat sekilas dari manuskrip tersebut, dapat terbaca bahwa karyanya tergolong multidisiplin. Meski membahas tentang berat benda, turut dibahas didalamnya terkait keseimbangan yang terjadi dalam alam dan kekuasaan Allah sebagai penyebabnya.

\section{Qatar Digital Library}

Qatar Digital Library mulanya adalah proyek bersama digitalisasi koleksi di perpustakaan nasional Qatar. Yang lantas, dalam pengumpulan koleksinya melakukan kerjasama dengan pihak 
The British Library. Termasuk kerjasama dalam mendanai proyek editing dan pemulihan suatu manuskrip hingga proses digitalisasinya.(Al-Mutawa 2019)

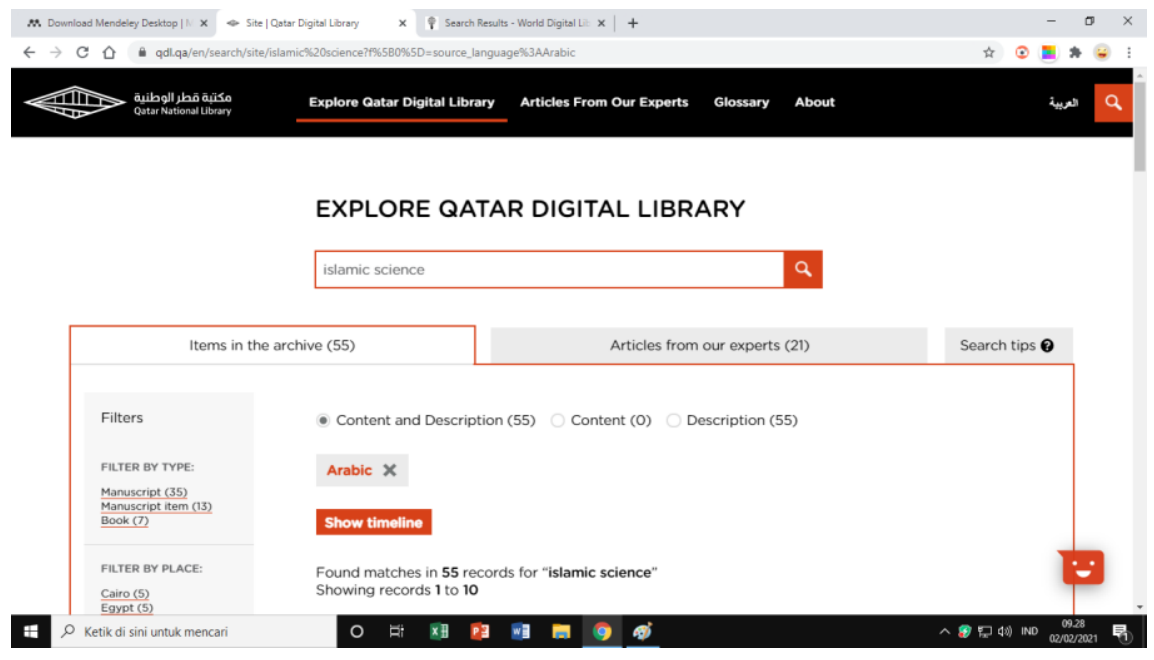

Gambar 3. Laman hasil penelusuran di Qatar Digital Library.

Terdapat 55 hasil dari penelusuran dengan kata kunci 'Islamic Science'. Berikut ini, adalah beberapa daftar sampel manuskrip karya saintis muslim yang dapat diakses secara online di Qatar Digital Library. Bidang yang diketahui dari manuskrip tersebut, di antaranya: Astronomi, Aritmatika, Kimia, dan Zoologi.

Tabel 3. Karya dan Penulis Manuskrip di Qatar Digital Library

\begin{tabular}{|c|c|c|c|}
\hline Nama Penulis & Tahun & Domisili & Periode \\
\hline $\begin{array}{c}\text { Thābit ibn } \\
\text { Qurrah }\end{array}$ & $836-901 \mathrm{M}$ & Iraq & Abbasiyah \\
\hline $\begin{array}{l}\text { 'Abd al-Raḥmān } \\
\text { al-Khāzinī }\end{array}$ & $1077-1120 \mathrm{M}$ & Iran & Seljuk \\
\hline $\begin{array}{c}\text { 'Alī ibn Hubal al- } \\
\text { Baghdādī }\end{array}$ & $1122-1213 \mathrm{M}$ & Irak & Abbasiyah \\
\hline $\begin{array}{c}\text { Aḥmad al-Mi'mār } \\
\text { al-Lahūrī }\end{array}$ & $\begin{array}{c}\text { Antara } 1632- \\
1700 \mathrm{M}\end{array}$ & India & Mogul \\
\hline Jābir ibn Hayyān & $721-813 \mathrm{M}$ & Iraq & Abbasiyah \\
\hline $\begin{array}{c}\text { ibn Husayn al- } \\
\text { 'Āmilī }\end{array}$ & $1547-1621 \mathrm{M}$ & Iran & Safawiyah \\
\hline al-Bīrūn̄̄ & $973-1048 \mathrm{M}$ & Iran & Abbasiyah \\
\hline Mūsá al-Damīrī & $1341-1405 \mathrm{M}$ & Mesir & Saljuk \\
\hline
\end{tabular}

Di antara koleksi yang terdapat di dalamnya, termasuk pula 
beberapa karya ilmuwan muslim terkenal seperti al-Bīrūnī. Salah satunya adalah al-Qanūn al-Mas'ūdì yang merupakan karya bidang astronomi yang didedikasikan kepada penguasa waktu itu. Yakni Sultan Mas'ūd of Ghaznī. Meskipun, karya tersebut merupakan salinan dari aslinya, yakni disalin usai tahun $1174 \mathrm{M}$ oleh seseorang yang tidak diketahui namanya.

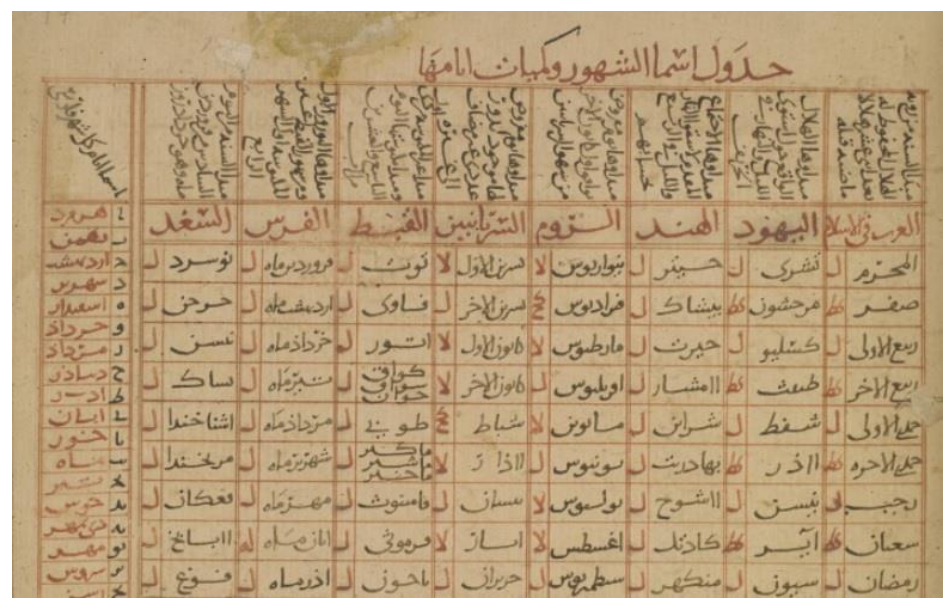

Gambar 4. Salinan manuskrip al- Bīrūnī bidang astronomi

Melihat konten dalam salinan tersebut, setidaknya dapat diketahui bahwa tertulis di dalamnya tabel tentang bulan yang dibandingkan antara kebudayaan dan agama masa itu. Termasuk Yahudi, Arab, Hindi, Qibti (Koptik - Mesir), dan Romawi.

\section{The British Library}

The British Library adalah perpustakaan nasional Inggris. Didirikan 1973 dengan menggabungkan beberapa institusi yang lebih tua dengan berbagai koleksinya. Tempat ini sekaligus perpustakaan untuk penyimpanan resmi. Sejak 2013, peraturan penyimpanan berkas telah dimodifikasi hingga mencakup sumber non-cetak, termasuk media elektronik. British Library juga memiliki koleksi yang dibeli dan disumbangkan dalam jumlah besar. Dalam mengindeks koleksinya, The British Library menggunakan berbagai metode. Salah satunya dengan LCSH (Library of Congress Subjects Headings) untuk mengklasifikasi literatur dan catatan perdagangan. Digunakan pula PRECIS (Preserved Context Index System) dan COMPASS (Computer 
Aided Subject System) dalam mengklasifikasi koleksi lokal (Ashton and Kent 2017).

Dengan banyaknya koleksi, kita perlu memilih tab katalog. Serta memilih penelusuran berjudul 'archive and manuscripts' (arsip dan manuskrip). Guna menemukan karya saintis muslim maupun ulama dengan bahasa Arab.

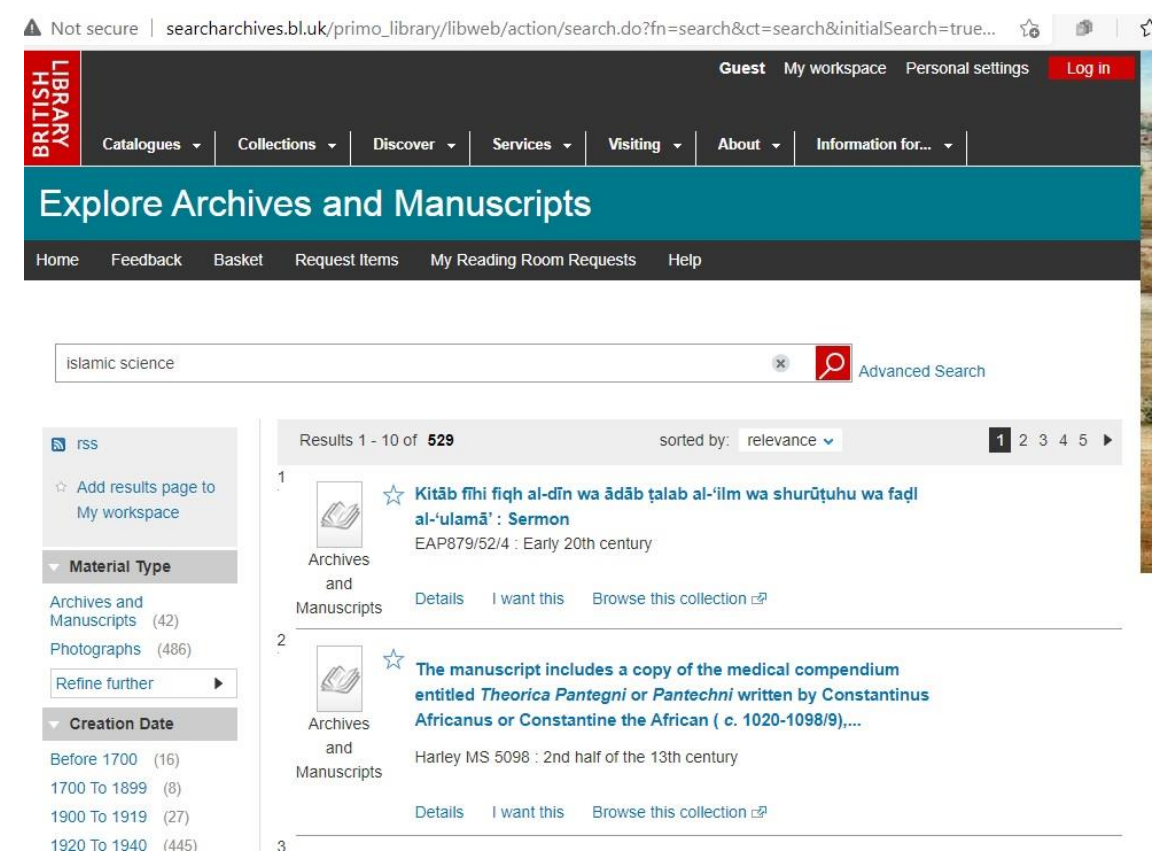

Gambar 5. penelusuran dengan kata kunci Islamic Science

Guna menemukan manuskrip Islam yang sesuai dengan tema, pada fitur penelusuran di web tersebut, digunakan kata kunci 'Islamic Science', dari penelusuran tersebut, ditemukan beberapa manuskrip sebagaimana di tabel di bawah ini:

Tabel 4. Beberapa Manuskrip di The British Library

\begin{tabular}{cccc}
\hline Nama Penulis & Tahun & Domisili & Periode \\
\hline $\begin{array}{c}\text { Ibn Mas'ūd al- } \\
\text { Shīrāzī }\end{array}$ & $1236-1310 \mathrm{M}$ & Persia & Saljuk (?) \\
$\begin{array}{c}\text { Sibt al-Mardini } \\
\text { Abed al-Qader }\end{array}$ & $1423-1506 \mathrm{M}$ & Kairo & Mamluk \\
$\begin{array}{c}\text { al-Maleki } \\
\text { Abdourahmane }\end{array}$ & $1631-1685 \mathrm{M}$ & Maroko & Maghribi \\
\end{tabular}


Orangzaib

'Ālamgīr.

$$
1618-1707 \mathrm{M}
$$

Balochistan

Mogul

Ibn Sīnā

980 - $1037 \mathrm{M}$

Iran

Abbasiyah

Derviş Nidai

Abad 16-17 M

Turki

Usmani

al-Qaṣīr al-

Anțāk̄̄

? - 1599

Kairo

Mamluk (?)

Yang menjadi karakteristik tersendiri dari manuskrip yang disimpan di British Library, bahwa selain terdapat banyak manuskrip dari tokoh terkenal seperti Ibnu Sina; terdapat pula sebagian besar darinya masih dalam proyek pemulihan. Karena, sebagian besar didapat dari daerah yang merupakan bekas jajahan bangsa Eropa di Afrika. Sehingga, kondisi manuskripnya tidak banyak yang utuh. Berikut pula data penulisnya tidak terlalu diperhatikan; meski dalam manuskripnya mengungkap beberapa info tentang waktu penulisan manuskrip tersebut. Salah satu proyeknya adalah pemulihan manuskrip dari Mali Afrika. Yakni, salah satu bekas kesultanan Mali pada masa itu. Yang pernah berpusat di Timbuktu. Namun kebanyakan, manuskripnya merupakan salinan dari murid-murid penulisnya. Karena, literature tersebut seperti bahan ajar yang sengaja disalin untuk diajarkan di halaqah-halaqah di masjid maupun pusat pembelajaran lainnya.

\section{Filaha Text Project}

Dalam perpustakaan online Filaha, secara khusus mengumpulkan manuskrip yang berkaitan dengan pertanian di era Islam. Peluncuran media daring ini dimulai oleh Dr. Karim Lahham. Yang mengkoordinir beragam museum dan kolektor manuskrip kuno berbahasa Arab tentang pertanian untuk diedit atau diterjemahkan.(Setia 2016) 


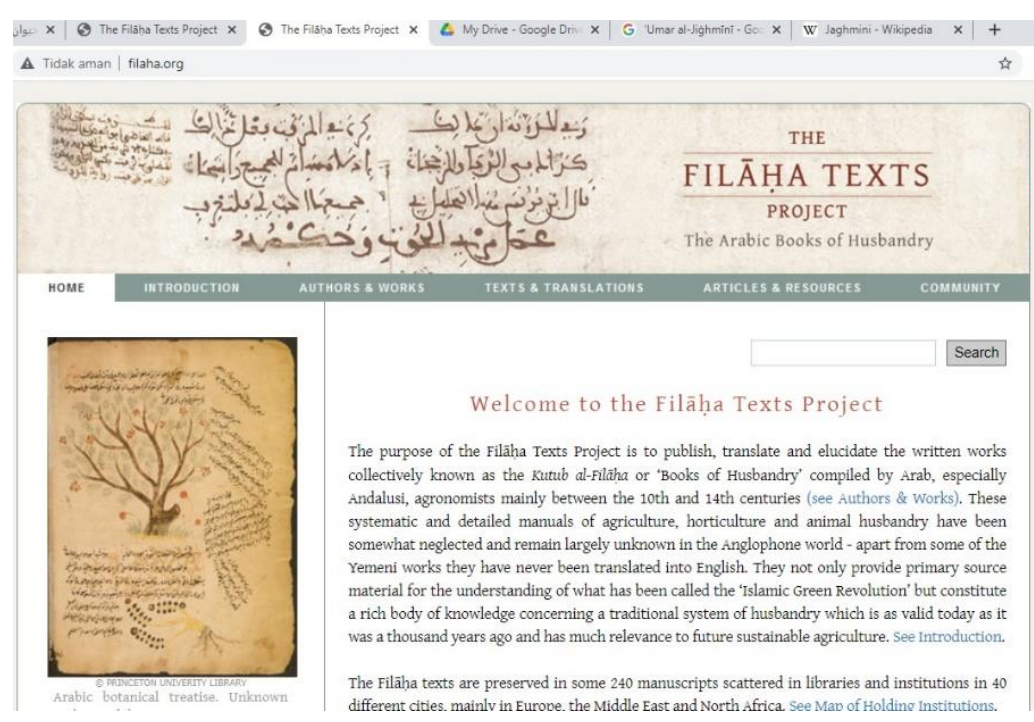

Gambar 7. Laman utama website filaha

Dalam website tersebut, terdapat laman tentang koleksi karya yang telah diedit dan ditranskrip maupun diterjemahkan ke dalam bahasa Inggris. Di antara karya-karya yang sudah diindeks dalam web ini adalah sebagai berikut:

Tabel 5. Sebagian Indeks Karya dan Penulis Manuskrip di al-Filaha

\begin{tabular}{|c|c|c|c|}
\hline Nama Penulis & Tahun & Domisili & Periode \\
\hline Ibn Wahshīya & c. 904 & Iraq & Abbasid \\
\hline 'Arīb ibn Sa'd & c. 912 - c. 980 & Cordoba & $\begin{array}{l}\text { Western } \\
\text { Umayyad }\end{array}$ \\
\hline $\begin{array}{l}\text { Anonymous } \\
\text { Andalusi }\end{array}$ & $\begin{array}{c}\text { fl. end } 10 \text { th } \mathrm{C} .- \\
\text { beg. } 11 \text { th } \mathrm{C} .\end{array}$ & Cordoba & $\begin{array}{l}\text { Western } \\
\text { Umayyad }\end{array}$ \\
\hline $\begin{array}{c}\text { Al-Nahrāwī / Al- } \\
\text { Zahrāwī }\end{array}$ & $\begin{array}{l}936 / 40- \\
1009 / 13\end{array}$ & Cordoba & $\begin{array}{l}\text { Western } \\
\text { Umayyad }\end{array}$ \\
\hline Ibn Wāfid & $\begin{array}{c}998 / 99 \text { or } \\
1007 / 08- \\
1074 / 75\end{array}$ & Toledo & Taifa \\
\hline Ibn Bașșāl & $\begin{array}{l}\text { mid } 11 \text { th } C .- \\
\text { beg. } 12 \text { th } C .\end{array}$ & Toledo/Seville & Taifa \\
\hline Ibn Hajjāj & fl. $1073 / 74$ & Seville & Taifa \\
\hline
\end{tabular}


Abū '1-Khayr

Ibn Waḥshīya fl. 2 nd half 11 th

C.

Seville

Taifa

c. 904

Iraq

Abbasid

Salah satu karya yang cukup terkenal, adalah milik Khayr al-Dīn ibn Ilyās yang berjudul Kitāb Falāh al-fallāh. Dalam laman ini, tidak disajikan manuskrip secara langsung. Melainkan telah ditranskrip maupun diedit dan diterjemahkan. Sehingga, website ini termasuk memberikan pendekatan berbeda dalam diseminasi manuskrip pertanian Islam.

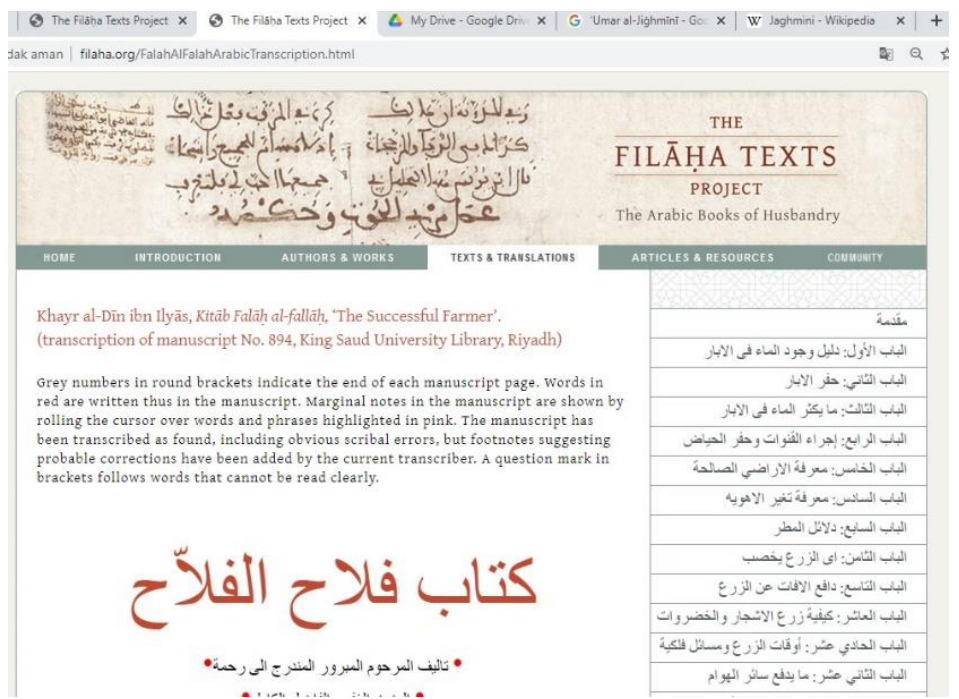

Gambar 8. Laman yang memuat Kitāb Falāḥ al-fallāh

Jika melihat kontennya, sangat jelas dan dapat dipahami bentuk hurufnya. Meski, yang menjadi kendala dalam memahami manuskrip jenis ini, adalah beberapa istilah teknis yang cenderung bersifat lokal. Sehingga, tidak banyak terdapat dalam kamus modern maupun kamus bahasa pada umumnya. Termasuk terma hawām yang artinya adalah semacam serangga.

Termasuk menjadi fakta menarik, bahwa tidak seluruh manuskrip dari berbagai website yang telah disebutkan di atas adalah karya asli dari penulisnya. Sebagian manuskrip diketahui merupakan salinan dari aslinya. Yang ditambah dengan komentar (syarh); yang demikian ini biasanya adalah salinan seorang murid dari karya gurunya. Misalnya, seperti karya Aidamur ibn 'Ali ibn Aidamur al-Jaldaki (? - 1342 M) yang berjudul Anwār 
al-bayān wa asrār al-burhān fĩ fahm awzān 'ilm al-mīzān yang sebagian ditulis ulang oleh muridnya yang dikenali sebagai Nur al-Din 'Ali ibn Aidamur (?). Manuskrip tersebut dapat diakses dari World Digital Library.

\section{Ucapan Terima Kasih}

Terima kasih kepada Lembaga Penelitian dan Pengabdian Masyarakat UNIDA Gontor yang telah mensponsori penelitian ini dengan nomor kontrak: 1315/UNIDA-LPPM/BA/SPK-P/I/2021

\section{PENUTUP}

\section{Simpulan}

Sudah menjadi maklum, bahwa diseminasi manuskrip sains Islam diharapkan dapat berkontribusi pada terselenggaranya berbagai kajian tentang sains Islam. Sebelumnya, kajian jenis ini hanya awalnya dilakukan oleh orientalis. Karena, mereka memiliki akses atas koleksi manuskrip kuno tersebut. Saat ini, dengan terbukanya beberapa akses menuju karya-karya saintis muslim yang berupa manuskrip asli, setidaknya kajian ini dapat mengusahakan adanya wacana kajian kritis dan pembacaan atas manuskrip tersebut. Apalagi, banyak sarjana muslim Indonesia yang memiliki kemampuan membaca bahasa Arab yang cukup baik. 


\section{DAFTAR PUSTAKA}

Abid, Abdelaziz. 2009. "The World Digital Library and Universal Access to Knowledge." URL: Http://Www. Unesco.

Org/New/Fileadmin/MULTIMEDIA/HQ/CI/CI/Pdf/Programme_doc_wdl. Pdf.

Al-Mutawa, Maryam Ahmed. 2019. "Qatar Digital Library: A New Phase of Digital Archives." Bibliothek Forschung Und Praxis 43(3):441-46.

Anwar, Muhammad Tajuddin, Husain Husain, and Nenet Natasudian Jaya. 2018. "Preservasi Naskah Kuno Sasak Lombok Berbasis Digital Dan Website." Jurnal Teknologi Informasi Dan Ilmu Komputer 5(4):445-54.

Ashton, Janet and Caroline Kent. 2017. "New Approaches to Subject Indexing at the British Library." Cataloging \& Classification Quarterly 55(7-8):549-59.

Cushman, Ellen. 2020. "Supporting Manuscript Translation in Library and Archival Collections: Toward Decolonial Translation Methods." Pp. 5368 in Libraries and Archives in the Digital Age. Springer.

Ghobrial, John Paul. 2016. "The Archive of Orientalism and Its Keepers: ReImagining the Histories of Arabic Manuscripts in Early Modern Europe." Past and Present.

Hendrawati, Tuty. 2019. "Digitalisasi Manuskrip Nusantara Sebagai Pelestari Intelektual Leluhur Bangsa." Media Pustakawan 25(4):21-29. Junawan, Hendra. 2020. "ANALYSIS OF DESIGN AND IMPLEMENTATION OF INFORMATION SYSTEM OF LIBRARY OF UIN SUNAN KALIJAGA JOGYAKARTA." IQRA: Jurnal Ilmu Perpustakaan Dan Informasi (eJournal) 14(2):73-90.

Ladewig, Stratton L. and Robert D. Marcello. 2019. "Presentation of the Center for the Study of New Testament Manuscripts: Bridging the Gap between Ancient Manuscripts and Modern Technology." Open Theology 5(1):451-60.

van Lit, L. W. C. 2019. "Digitized Manuscripts and Their Repositories, an Ethnography." Pp. 73-101 in Among Digitized Manuscripts. Philology, Codicology, Paleography in a Digital World. Brill.

Lliteras, Susana Molins. 2020. "Iconic Archive: Timbuktu and Its Manuscripts in Public Discourse." Babel Unbound: Rage, Reason and Rethinking Public Life 144.

Mochammad, Rozikin, Rindi Ardika, and Teguh Yudi Cahyono. 2020. "Library 4.0: Eco-Blended Library and Library Inclusion." Khizanah AlHikmah: Jurnal Ilmu Perpustakaan, Informasi, Dan Kearsipan 8(2):11629.

Muslih, Mohammad. 2016. "Al-Qur'an Dan Lahirnya Sains Teistik." TSAQAFAH 12(2).

Nasreen, Nahida, Bisma Bashir, and Fayaz Ahmad Loan. 2019. "World Digital Library: An Analysis of Collection." World 4:19-2019.

Nugroho, Achmad Agung and Niken Ayu Isnainy. 2020. "Penggunaan Aplikasi OPAC Untuk Meningkatkan Kualitas Manajemen Pelayanan Perpustakaan." JoIEM (Journal of Islamic Education Management) 1(1). 
Van Oudenaren, John. 2017. "The World Digital Library." Bibliothek Forschung Und Praxis 41(2):242-49.

Pertiwi, Putri Meri Yanti and others. 2020. "Daftar Pengunjung Perpustakaan Berbasis Elektronik Di Perpustakaan STIKES Alifah Padang." Jurnal Pustaka Budaya 7(2):97-104.

Prastiani, Intan and Slamet Subekti. 2019. "Digitalisasi Manuskrip Sebagai Upaya Pelestarian Dan Penyelamatan Informasi (Studi Kasus Pada Museum Radya Pustaka Surakarta)." Jurnal Ilmu Perpustakaan 6(3):141-50.

Riedel, Dagmar A. 2015. "Manuscripts, Printed Books, and Near Eastern Studies in North America: The Manuscripts in Arabic Script of the Columbia University Libraries." Journal of Islamic Manuscripts.

Sahidi, Sahidi. 2020. "PERAN KEPUSTAKAAN DAN PERPUSTAKAAN DALAM MEMBANGUN PERADABAN ISLAM (Sebuah Tinjauan Historis Peradaban Perpustakaan Islam)." IQRA: Jurnal Ilmu Perpustakaan Dan Informasi (e-Journal) 14(2):146-69.

Setia, Adi. 2016. "Vision in Action: Operationalising the Islamisation of Science and Technology." in Islamic Perspectives on Science and Technology.

Wibowo, Diki Tri and Lydia Christiani. 2018. "Peran Arsip Digital Naskah Kuno Pada Website Yayasan Sastra Lestari Dalam Diseminasi Informasi Kesusastraan Jawa." Jurnal Ilmu Perpustakaan 7(3):211-20.

Woldeyes, Yirga Gelaw. 2020. "Holding Living Bodies in Graveyards': The Violence of Keeping Ethiopian Manuscripts in Western Institutions." $M / C$ Journal.

Ye, Christine, Charles F. Hofacker, John Peloza, and Alexis Allen. 2020. "How Online Trust Evolves over Time: The Role of Social Perception." Psychology \& Marketing 37(11):1539-53. 